This item was submitted to Loughborough's Research Repository by the author.

Items in Figshare are protected by copyright, with all rights reserved, unless otherwise indicated.

\title{
Impact of occupant behaviour on the energy-saving potential of retrofit measures for a public building in the UK
}

PLEASE CITE THE PUBLISHED VERSION

http://dx.doi.org/10.1080/17508975.2016.1139538

PUBLISHER

(c) Taylor \& Francis

\section{VERSION}

AM (Accepted Manuscript)

\section{PUBLISHER STATEMENT}

This work is made available according to the conditions of the Creative Commons Attribution-NonCommercialNoDerivatives 4.0 International (CC BY-NC-ND 4.0) licence. Full details of this licence are available at: https://creativecommons.org/licenses/by-nc-nd/4.0/

\section{LICENCE}

CC BY-NC-ND 4.0

\section{REPOSITORY RECORD}

Wei, Shen, Tarek M. Hassan, Steven K. Firth, and Farid Fouchal. 2019. "Impact of Occupant Behaviour on the Energy-saving Potential of Retrofit Measures for a Public Building in the UK". figshare. https://hdl.handle.net/2134/20499. 


\title{
Impact of occupant behaviour on the energy saving potential of refurbishment measures for a public building in the UK
}

\author{
Shen Wei, Tarek M Hassan, Steven Firth, Farid Fouchal \\ School of Civil and Building Engineering, Loughborough University, UK
}

\begin{abstract}
In building refurbishment projects, dynamic building simulation is popularly used to predict the energy saving potential of various refurbishment scenarios. However, in this process, it is not clear whether occupant behaviour should be carefully modelled due to the lack of evidence about its impact on the prediction results. To answer this question, this study selected an UK public building and used dynamic building simulation to predict the energy saving potential of common refurbishment measures, under various occupant behavioural conditions. The results revealed that for the case study building occupants' heating behaviour has a significant impact on the predicted energy saving potential of all evaluated refurbishment measures: when changing from passive heating users to active heating users, the energy saving potential was nearly doubled. Although occupants' window opening behaviour was not shown to be as important as heating behaviour for the refurbishment of the case study building, it has a specific influence on the refurbishment measure of increasing window layers: when windows are opened longer, the effectiveness of increasing window layers on promoting the building energy efficiency is decreased. According to the findings from this study, occupant behaviour should be considered as an important aspect in building refurbishment projects.
\end{abstract}

Keywords: building refurbishment, public building, occupant behaviour, building simulation, energy efficiency

\section{Introduction}

In order to achieve sustainable development of our society, energy refurbishment of existing buildings for improving their energy efficiency has become an inevitable task for the governments of many countries (DOE 2009; GOV 2015; CBRE 2011).

Generally, a sustainable building refurbishment programme consists of five key phases, from the project setup and pre-refurbish survey phase to the validation and verification 
phase (Ma et al. 2012). In this process, identification of retrofit options using reliable data is essential for a successful building refurbishment project. To provide evidence for selecting suitable refurbishment measures, dynamic building performance simulation tools, such as TRNSYS (Santamouris et al. 2007), EnergyPlus (Wei, Jones, and de Wilde 2014; Ascione, de Rossi, and Vanoli 2011; Chidiac et al. 2011), IES VE (Ben and Steemers 2014) and DOE-2 (Zmeureanu 1990), have been widely used in real projects.

When using dynamic building performance simulation, however, a significant gap between the predicted performance of buildings and the actual one usually exists (de Wilde 2014), which influences the reliability of using simulation to help design buildings. Occupant behaviour in buildings, e.g. heating behaviour, window opening behaviour, has been suggested to be one of the main aspects causing this gap (de Wilde 2014), due to its great impact on the building performance, which has been demonstrated in a number of existing studies using data from either real buildings (Mulville, Jones, and Huebner 2013; Yu et al. 2011; Gram-Hassen 2010; Gill et al. 2010; Brown, Dowlatabadi, et al. 2009; Bağc1 2009; Guerra Santin, Itard, and Visscher 2009; Steemers and Yun 2009; Hass, Auer, and Biermayr 1998) or building simulation (Bonte, Thellier, and Lartigue 2014; Lee and Malkawi 2014; Mavrogianni et al. 2014; Roetzel 2014; Silva and Ghisi 2014; de Meester et al. 2013; Fabi, Andersen, and Corgnati 2013). These studies, however, focused on the building design stage and operation stage, while the impact of occupant behaviour in the building refurbishment stage still requires further exploration, especially its impact on the predicted energy saving potential of refurbishment measures by dynamic building performance simulation. 
To fill this gap, the research team authoring this paper has chosen a UK public building that is under planned to be refurbished for reducing its heating demand in winter. In order to evaluate the impact of various occupant behaviour on the energy saving potential of common refurbishment measures, the case study building was modelled using a popular dynamic building performance simulation tool. Then different window and heating users (active and passive users) were positioned inside the building for both pre-refurbish and post-refurbish scenarios, and the impact from occupant behaviour on the energy saving potential of each refurbishment measure was demonstrated through the difference between the predicted energy saving potential of that measure when the building was occupied by active window/heating users and that when it was occupied by passive window/heating users. The results introduced in this paper reflect the importance of occupant behaviour on the predicted effectiveness of common refurbishment measures, and so provide evidence on whether occupant behaviour should be carefully considered when calibrating dynamic building simulation models for refurbishment decision makings.

\section{Methodology}

\subsection{Experimental building}

The experimental building (Figure 1) selected for the study was located on the campus of ?? University in the east-midlands region of England (52 $45^{\prime} 54^{\prime \prime} \mathrm{N}, 1^{\circ} 14^{\prime} 15^{\prime}$ ' $\mathrm{W}$, alt. $70 \mathrm{~m}$ ). The building was chosen because it represents a big number of old office buildings in the UK, which have poor thermal insulation for the façade and significant air leakage, leading to huge energy waste. Due to this issue, the Facility Management (FM) team of the university has decided to carry out an energy refurbishment for the building at early 2016 to promote its energy performance, and the results expressed in 
this paper have been used to guide their decision making on suitable refurbishment strategies.

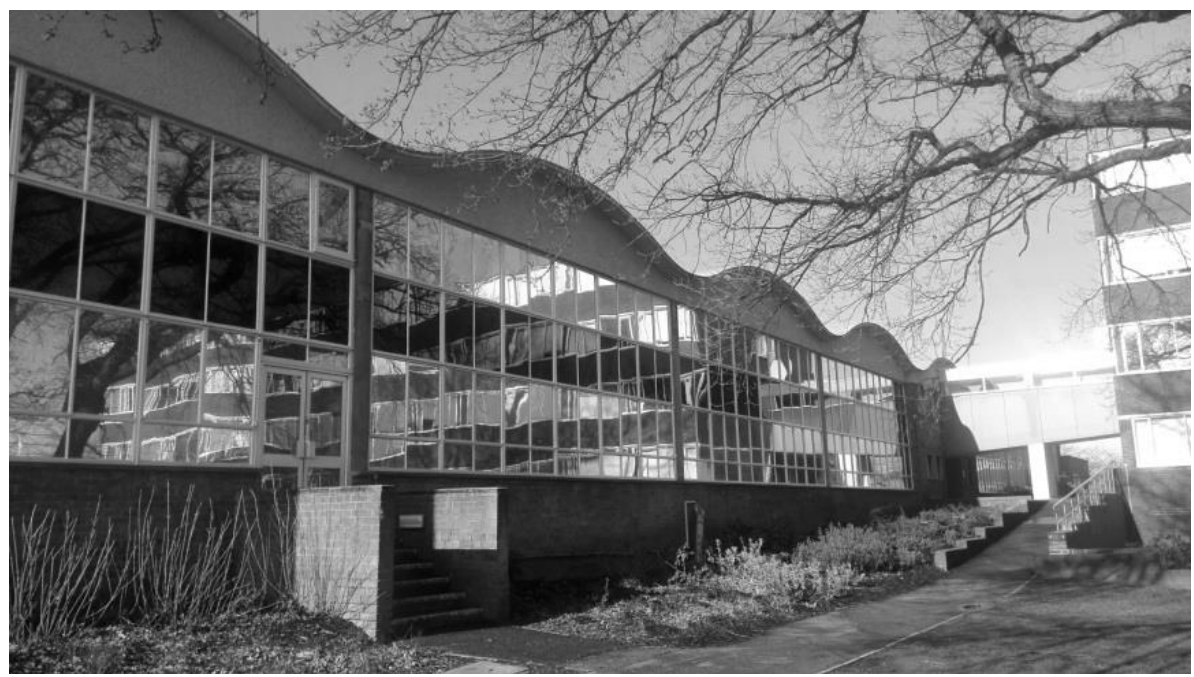

Figure 1. The experimental building.

The building faces northeast and some parts of the northeast, northwest and southeast facades are connected with other buildings. It was built in 1958 and some preliminary retrofitting work has been performed in 2006, such as upgrading the heating control system with functions to adjust the temperature of individual rooms. The building is composed of a number of rooms for office work and some rooms for lab work. The building facade was mainly built with clear windows and it has a Window to Wall Ratio (WWR) about 70\%. In the first and third rows, about half windows can be opened by the occupants to a maximum opening area of about $20 \%$ of the glazing area, and the remaining ones are fixed. The colourful membranes attached to the second row from the top are designed mainly for privacy and decoration purposes and their impact on solar penetration is very weak. The building was built on a hill so the ground level of the back side of the building is about $1 \mathrm{~m}$ higher than the front side. Table 1 lists definitions of some important construction components of the building, which will be used later to build the base case simulation model. The data were provided by the FM according to the initial design of the building. In winter, the building is heated by a district heating 
system covering the Central Park of the university campus, generally starting from the beginning of October and ending at the end of March (Wei, Buswell, and Loveday 2013).

Table 1. Building construction definitions.

\begin{tabular}{|c|c|}
\hline & Material (Outermost to Innermost) \\
\hline External wall & 4.5 ' Brick +2.0 ' Cavity +4.5 ' Brick \\
\hline Pitched roof & 0.75 ' Asphalt +2.5 ' reinforced concrete +0.5 ' Asbestos \\
\hline Ground floor & 6.0 ' Hardcore +10.5 ' Concrete +1.5 ' Floor finish \\
\hline External window & Single glazing (6mm glazing) \\
\hline
\end{tabular}

\subsection{Building performance simulation}

Dynamic building performance simulation was performed using DesignBuilder V4.2 on an hourly basis. DesignBuilder (DesignBuilder 2005) is the first comprehensive user interface of EnergyPlus (DOE), and DesignBuilder V4.2 adopts EnergyPlus 8.1 as the engine for dynamic building performance simulation. The simulation work in this study was carried out between 1st October and 31st March, following the general heating period of the university. According to the construction component definitions listed in Table 1 and relevant geometry information provided by the FM, a base case simulation model was developed as shown in Figure 2.

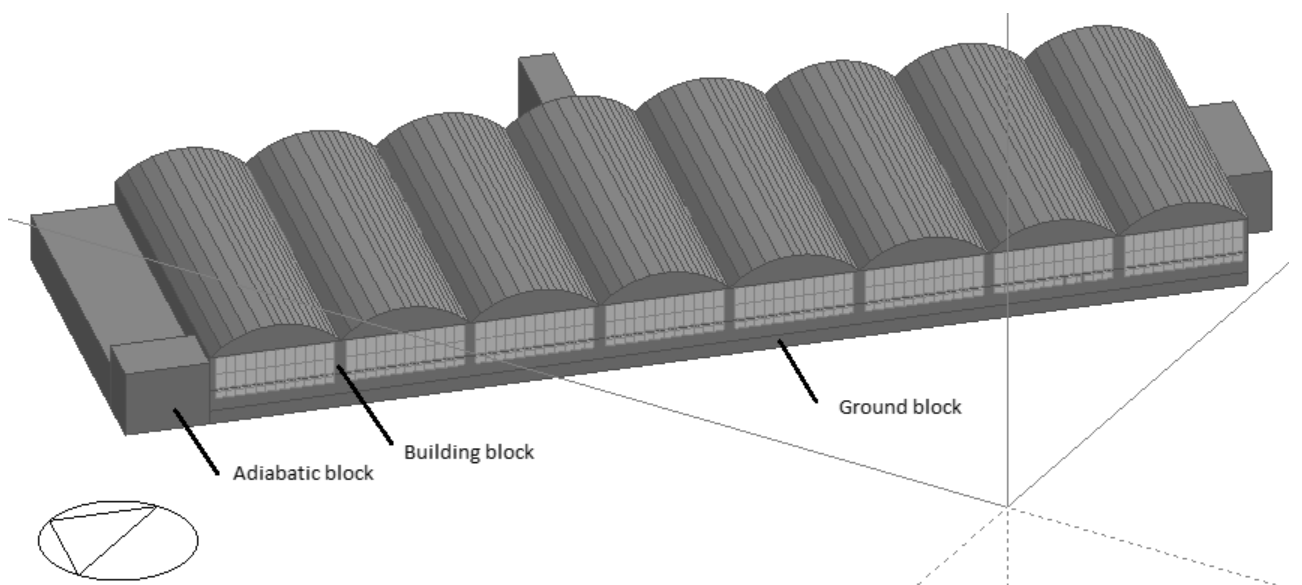

Figure 2. Thermal model of the experimental building in DesignBuilder. 
To build this model, three types of blocks defined in DesignBuilder were used, namely building block, adiabatic block and ground block (DesignBuilder): the building block was used to define components of building construction; the adiabatic block was used to define any adjacent buildings; the ground block was used to define the adjacency of any touching building block surfaces as being 'adjacent to ground'. Table 2 lists the definitions of important properties of some building components, such as airtightness level, external wall insulation, pitched roof insulation and window type, before and after the building was refurbished.

Table 2. Definitions of building components before and after retrofitting.

\begin{tabular}{|c|c|c|}
\hline & $\begin{array}{c}\text { Before retrofitting } \\
\text { (base case) }\end{array}$ & After retrofitting \\
\hline Airtightness $^{1}$ & Poor & Good \\
\hline External wall & U-value $=1.493 \mathrm{~W} / \mathrm{m}^{2} \mathrm{~K}$ & U-value $=0.746 \mathrm{~W} / \mathrm{m}^{2} \mathrm{~K}$ \\
\hline Pitched roof & U-value $=4.035 \mathrm{~W} / \mathrm{m}^{2} \mathrm{~K}$ & U-value $=2.009 \mathrm{~W} / \mathrm{m}^{2} \mathrm{~K}$ \\
\hline External & Single glazing & Double glazing \\
window & $(6 \mathrm{~mm}$ glazing $)$ & $(6 \mathrm{~mm}$ glazing $+6 \mathrm{~mm}$ air gap $)$ \\
\hline
\end{tabular}

The refurbishment work introduced here focused on increasing the insulation level of the experimental building using various strategies, which were discussed by the researchers of this study and the University FM team to have high priorities according to the current condition of the building (refurbishment strategies regarding to heating systems were not considered in this study because the building is heated by a district heating system in the university and controllability of individual rooms has been installed in the retrofitting work done in 2006). The refurbishment strategies considered in this study included an upgrading of building airtightness, increasing the thermal

\footnotetext{
${ }^{1}$ Detailed definition on airtightness in DesignBuilder is available at http://www.designbuilder.co.uk/helpv3/Content/_Calculated_ventilation_data_detail11.htm
} 
insulation of external walls and the pitched roof and replacing all windows from single glazing to double glazing. In the simulation, the building was assumed to be occupied between 9:00am and 5:00pm, based on a standard office working schedule in the UK. As heating and window operations have been identified in previous studies as the most important behavioural types affecting the building heating demand in winter (Ben and Steemers 2014; Wei, Jones, and de Wilde 2014), their impact on the predicted energy saving potential of refurbishment measures by simulation was evaluated in this study. This evaluation was carried out by locating extreme window and heating users to the experimental building and comparing the predicted energy saving potential of each refurbishment measure under different behavioural conditions, so the largest possible impact from various occupant behaviour on the prediction result can be identified, hence reflecting the importance of well capturing occupants' actual behaviour on the selection of refurbishment strategies. Equation 1 was used to calculate the energy saving potential of each refurbishment measure.

$$
E_{\text {pre-retro }}-E_{\text {post-retro }}=E_{\text {saving }}
$$

Where

$\mathrm{E}_{\text {pre-retro }}$ is the building's heating energy demand before the refurbishment measure applies, in kWh;

$\mathrm{E}_{\text {post-retro }}$ is the building's heating energy demand after the refurbishment measure applies, in kWh.

With respect to defining extreme window and heating users, only two existing studies have been found that are based on field measured data in real buildings, one for heating behaviour (Ben and Steemers, 2014) and another for window behaviour (Wei 2014). According to these publications, active heating users were defined as those who 
set heating temperature as $24^{\circ} \mathrm{C}$, and passive heating users were those who set heating temperature to be $18^{\circ} \mathrm{C}$; active window users were defined as those who always keep windows open, and passive window users were those who always keep windows closed.

\section{Results and discussion}

\subsection{Impact from heating behavior}

When evaluating the impact of heating behaviour on the energy saving potential of refurbishment measures, windows were assumed to be always closed. Table 3 has listed the raw predicted energy consumption of the building under various physical and behavioural conditions.

Table 3. Predicted heating demand for various heating users.

\begin{tabular}{|c|c|c|c|}
\hline & \multicolumn{2}{|c|}{ Heating demand (kWh) } & Increasing \\
\cline { 2 - 4 } & $\begin{array}{c}\text { Passive heating users } \\
\left.\text { (temperature 18} \mathbf{~}^{\circ} \mathbf{C}\right)\end{array}$ & $\begin{array}{c}\text { Active heating users } \\
\left.\text { (temperature 24}{ }^{\circ} \mathbf{C}\right)\end{array}$ & \\
\hline Base case & $381,516(0 \%)$ & $696,399(0 \%)$ & $83 \%$ \\
\hline $\begin{array}{c}\text { Airtightness } \\
\text { improved }\end{array}$ & $307,345(-19 \%)$ & $568,100(-18 \%)$ & $85 \%$ \\
\hline $\begin{array}{c}\text { External wall } \\
\text { insulation increased }\end{array}$ & $372,358(-2 \%)$ & $680,228(-2 \%)$ & $83 \%$ \\
\hline $\begin{array}{c}\text { Pitched roof } \\
\text { insulation increased }\end{array}$ & $266,051(-30 \%)$ & $508,539(-27 \%)$ & $91 \%$ \\
\hline $\begin{array}{c}\text { Window layer } \\
\text { increased }\end{array}$ & $362,087(-5 \%)$ & $663,324(-5 \%)$ & $83 \%$ \\
\hline
\end{tabular}

The 'base case' simulation scenario is based on the current physical conditions of the case study building (see Table 2) and in the following scenarios each building component investigated was changed sequentially to represent various refurbishment strategies. The values in the brackets indicate the percentage reduction in heating 
demand for each refurbishment measure (i.e. the percentage of saved energy in the total energy consumption of the base case scenario), and the last column in Table 3 lists the increasing rate on energy consumption due to the change of building use, that is, from passive heating users to active heating users in this case. From the data shown in the last column of the table, it could be found that occupant heating behaviour has a significant influence on the building's heating demand in winter: the heating energy consumption increased by more than $80 \%$ when changing from passive heating users to active heating users. This result is consistent with findings from existing studies, as listed in the introduction section of the papers. With respect to building refurbishment, the data reflect that upgrading the insulation of the pitched roof has the biggest energy saving potential for the case study building, while increasing the external wall insulation has the smallest energy saving potential.

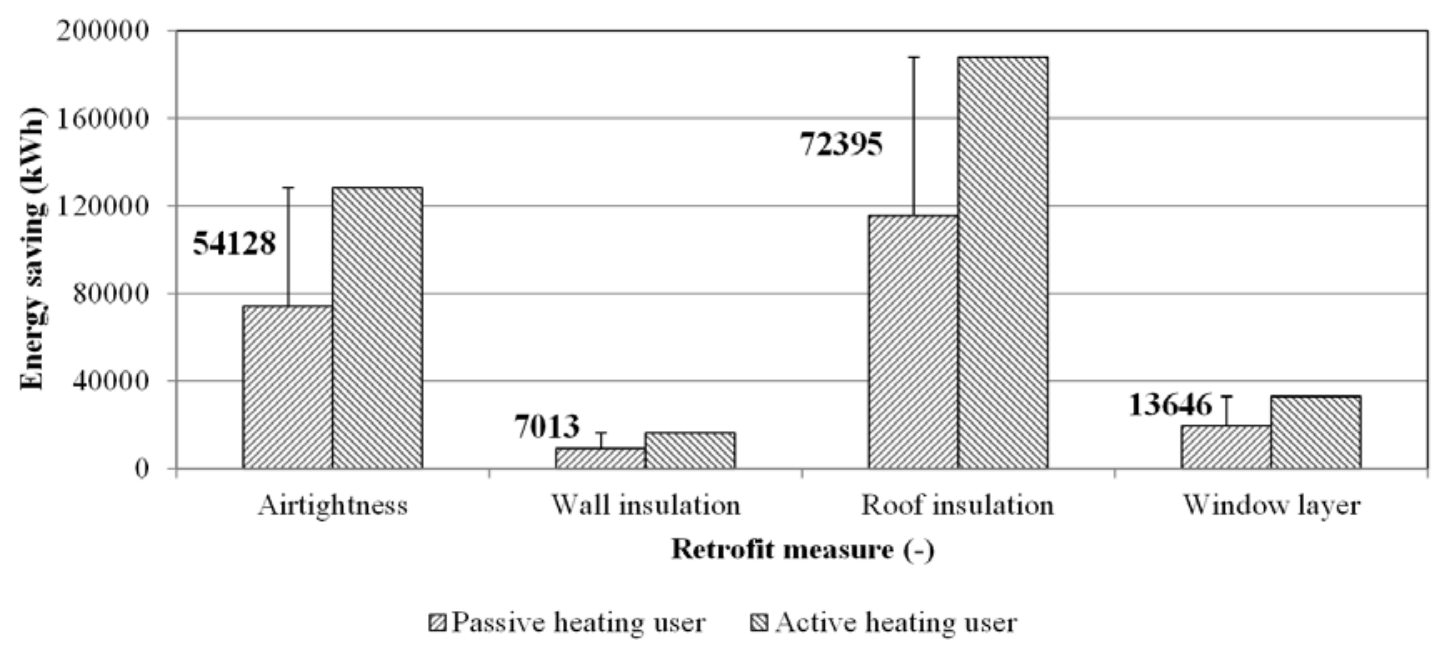

Figure 3. Comparison of energy saving potential of different retrofit measures for various heating conditions.

Based on the data listed in Table 3, the energy saving potential of each refurbishment measure tested in the study was calculated using Equation 1. Figure 3 compares the energy saving potential of each refurbishment measure at different heating operation conditions. For each refurbishment measure, the first column shows the energy saving potential when the building was occupied by passive heating users, and 
the second column presents the value when the building was occupied by active heating users. The comparison clearly shows that occupants' heating behaviour has a significant impact on the predicted energy saving potential of all refurbishment measures: when the building was occupied by active heating users, the energy saving potential of all refurbishment measures was increased significantly, comparing to that when occupied by passive heating users (the energy saving potential when occupied by active heating users was nearly twice as much as that when occupied by passive users). This reflects that if the building was occupied by passive heating users in reality but active heating users were used to estimate the energy saving potential of one refurbishment measure, the potential contribution of that refurbishment measure to reducing building heating demand will be greatly overestimated, and this overestimation will influence the calculation of some key performance indicators (KPIs), such as the payback period (Cohen, Goldman, and Harris 1991), which will be used to help choose most suitable refurbishment measures for the project.

\subsection{Impact from window opening behavior}

When evaluating the impact of window opening behaviour on the energy saving potential of refurbishment measures, the indoor heating temperature was assumed to be $24^{\circ} \mathrm{C}$. Table 4 lists the raw predicted energy consumption of the building under various physical and behavioural conditions. From the predicted results listed in the last column of the table, it could be found that changing window behaviour does not affect the heating energy demand, as significantly as changing heating behaviour (7\%-10\% comparing to 83\%-91\%). This may due to the characteristics of both small number of openable windows (less than $30 \%$ of all windows) and small window opening area (20\% of the total window area) of this building. The same as for various heating conditions, upgrading roof insulation showed the biggest energy saving potential and 
increasing external wall insulation has the smallest one.

Table 4. Predicted heating demand for various window users.

\begin{tabular}{|c|c|c|c|}
\hline \multirow{2}{*}{} & \multicolumn{2}{|c|}{ Heating demand (kWh) } & Increasing \\
\cline { 2 - 4 } & $\begin{array}{c}\text { Passive window } \\
\text { users } \\
\text { (window always } \\
\text { closed) }\end{array}$ & $\begin{array}{c}\text { Active window users } \\
\text { (window always } \\
\text { open) }\end{array}$ & \\
\hline Base case & $696,399(0 \%)$ & $746,695(0 \%)$ & $7 \%$ \\
\hline $\begin{array}{c}\text { Airtightness } \\
\text { improved }\end{array}$ & $568,100(-18 \%)$ & $612,149(-18 \%)$ & $8 \%$ \\
\hline $\begin{array}{c}\text { External wall } \\
\text { insulation increased }\end{array}$ & $680,228(-2 \%)$ & $729,832(-2 \%)$ & $7 \%$ \\
\hline $\begin{array}{c}\text { Pitched roof } \\
\text { insulation increased }\end{array}$ & $508,539(-27 \%)$ & $558,130(-25 \%)$ & $10 \%$ \\
\hline Window layer & $663,324(-5 \%)$ & $716,128(-4 \%)$ & $8 \%$ \\
\hline increased & & & \\
\hline
\end{tabular}

Similar to heating behaviour, the energy saving potential of each refurbishment measure tested in this study was calculated using Equation 1 for different window opening conditions and results are compared in Figure 4.

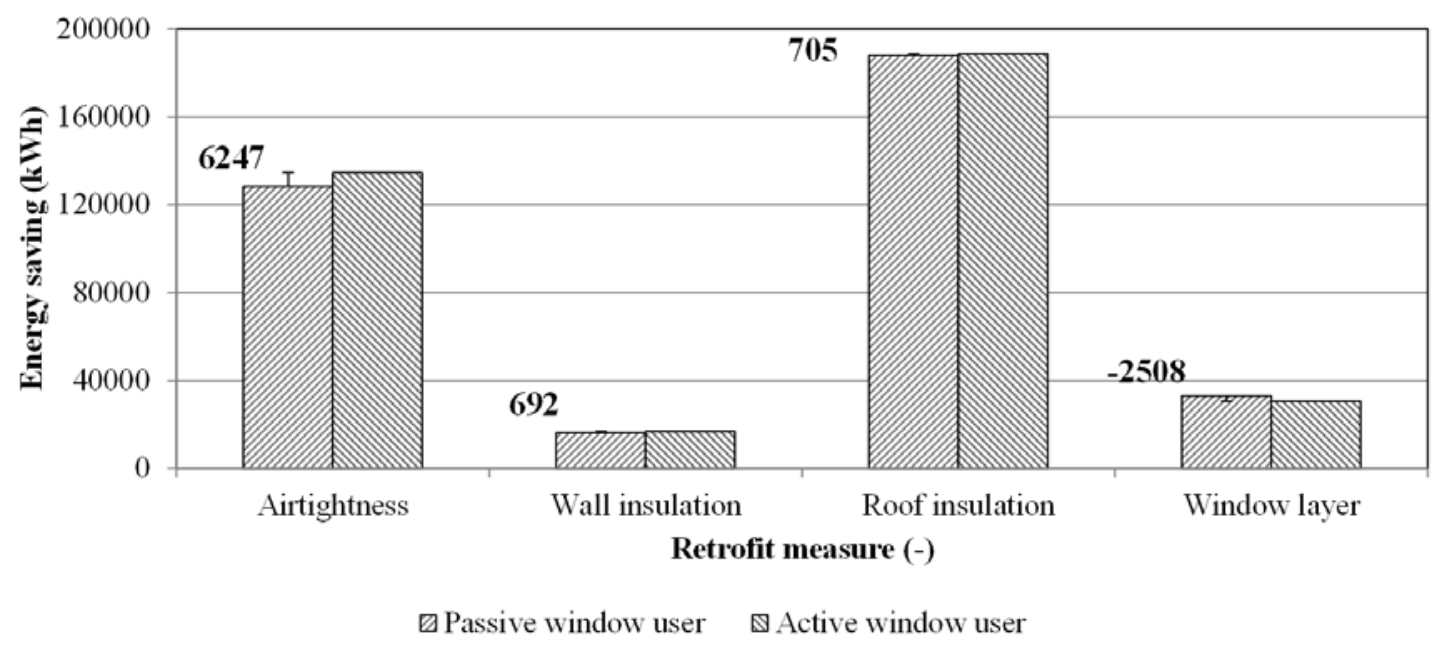

Figure 4. Comparison of energy saving potential of different retrofit measures for various window opening conditions. 
From the comparison, it can be observed that window opening behaviour has a moderate impact on the predicted energy saving potential of all refurbishment measures in this building, as the calculated values showed a good consistency when the building was occupied by active and passive window users, respectively. Due to the special condition that the case study building has a small proportion of openable windows and a small window opening area, different conclusions could be made for other buildings that have higher proportion of openable windows or higher window opening area, and this hypothesis needs further investigations in future studies. Although the impact is not very significant (maximum difference is $8 \%$ among all calculated energy saving potentials), the simulation result for the refurbishment measure of increasing window layers is different from those for the other three refurbishment measures: the predicted impact is negative for this refurbishment measure while for the other three measures the impact is positive. This means that if the windows are opened more, the contribution of increasing window layers to reducing building heating demand is reduced. A possible reason is that when the window is closed, the main heat loss through the window is heat conduction, driven by the temperature difference between indoors and outdoors, as shown in Figure 5a. Meanwhile, a small amount of heat will be lost through the cracks around the window, driven by either buoyancy or wind (CIBSE 2005). Under this condition, that is when the window is closed, the insulation level of the window directly determines the amount of heat transferred from indoors to outdoors through heat conduction. When the window is opened, cold outdoor air will go inside the room from the bottom part of the window, while warm indoor air will escape to outdoors from the top part of the window (CIBSE 2005), as shown in Figure 5b. Under this condition, the main heat loss is ventilation. With the cold air going inside the room, the temperature difference between the two sides of the window is reduced, and therefore heat loss by 
heat conduction is not as significant as when the window is closed. When heat conduction is not the main heat loss mechanism, increasing window layers becomes less important to the energy efficiency of the building.

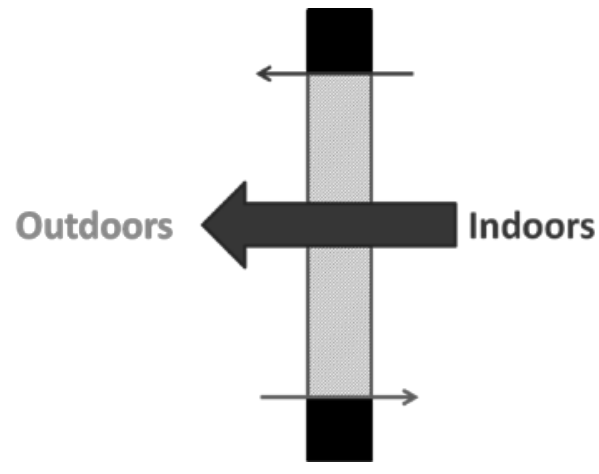

(a) Window closed

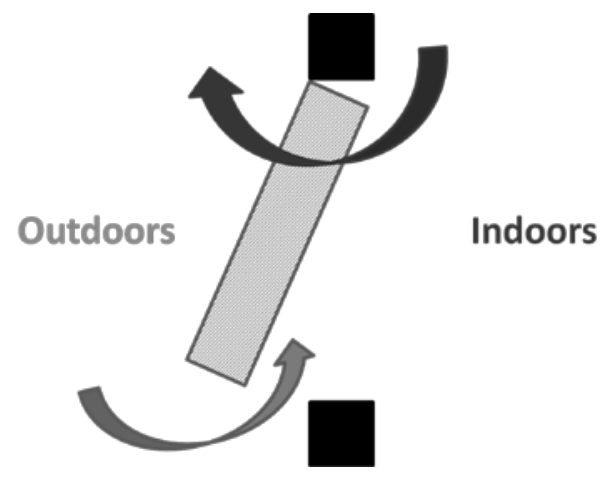

(b) Window opened

Figure 5. Heat loss for different states of windows.

\section{Conclusions}

In sustainable building refurbishment projects, dynamic building performance simulation is being used to help select most suitable refurbishment measure(s), by predicting the energy saving potential of both individual refurbishment measures and a combination of several measures. In this prediction process, whether occupant behaviour should be well modelled still needs further justification. To answer this question, this study used a real building located on the campus of ?? University, UK, and analysed the impact of occupants' heating and window opening behaviours on the predicted energy saving potential of common refurbishment measures. Main conclusions from this study include:

(1) Occupant heating behaviour has a significant impact on the predicted energy saving potential of refurbishment measures by dynamic building performance simulation, for the case study building chosen in this study. Changing indoor air 
temperature from $18^{\circ} \mathrm{C}$ to $24^{\circ} \mathrm{C}$ will almost double the energy saving potential of all tested refurbishment measures;

(2) The impact from window opening behaviour seems to be not important for most refurbishment measures for the case study building as the predicted energy saving potential under various window operation conditions shows good consistency. However, due to the special characteristics of windows in the case study building, more studies are still required in the future to prove this conclusion;

(3) Opening windows longer will reduce the contribution of upgrading window layers to increasing the energy efficiency of the case study building. This maybe because that when the window is opened, ventilation rather than heat conduction becomes the principle heat loss mechanism through the window.

In summary, this paper has provided evidence that occupant behaviour has a significant influence on the predicted energy saving potential of refurbishment measures by dynamic building performance simulation. For the case study building, heating behaviour influences all common refurbishment measures and window opening behaviour influences specific measures. Therefore, it is suggested that when using dynamic building performance simulation to help choose suitable refurbishment measures for building refurbishment projects, occupants' actual behaviour should be well monitored for a sufficient period of time to calibrate the simulation model, by correcting the behavioural patterns assumed in building simulation. Currently, a number of methods are available to help monitor principle occupant behaviour, e.g. window behaviour and heating behaviour, in buildings, for example, self-recording by the building occupants (Haldi and Robinson, 2008; Raja et al.), electronic measurement devices (Spataru and Gillott 2011, Yun and Steemers, 2010), surveyor observation (Wei 
et al. 2013; Zhang and Barrett, 2012) and self-estimation by the building occupants (Guerra Santin, 2013; Huang et al. 2014). A deep understanding of the advantages and disadvantages of each method is still highly needed so the most suitable method for refurbishment applications can be identified. If this monitoring work is not possible, the impact of occupant behaviour on the predicted energy saving potential should be well considered when selecting refurbishment measures according to the simulation results, possibly through sensitivity analysis and uncertainty analysis. Additionally, occupant behaviour before refurbishment should use the current behaviour to realistically reflect the current operation condition of the building but occupant behaviour after refurbishment can be adjusted with a consideration of energy conservation, as long as proper occupant education on the building usage (Agha-Hossein, Tetlow, et al. 2015) or suitable mechanical control strategies to reduce energy waste (Yang and Wang, 2013) are considered during the refurbishment work.

\section{Acknowledgements}

\section{References}

Agha-Hossein, M. M., Tetlow, R. M., Hadi, M., El-Jouzi, S., Elmualim, A. A., Ellis, J. and Williams, M. 2015. Providing persuasive feedback through interactive posters to motivate energy-saving behaviours, Intelligent Buildings International 7(1): 16-35.

Ascione, F., de Rossi, F., and Vanoli, G.P. 2011. Energy retrofit of historical buildings: theoretical and experimental investigations for the modelling of reliable performance scenarios, Energy and Buildings, 43 (8) 1925-1936. 
Bağc1, B. 2009. Energy saving potential for a high-rise office building, Intelligent Buildings International 1(2): 156-163.

Ben, H., and Steemers, K. 2014. Energy retrofit and occupant behaviour in protected housing: A case study of the Brunswick Centre in London, Energy and Buildings, 80 (0) 120-130.

Bonte, M., Thellier, F., and Lartigue, B. 2014. Impact of occupant's actions on energy building performance and thermal sensation, Energy and Buildings, 76 (0) 219227.

Brown, Z. B., Dowlatabadi, H. and Cole, R. J. 2009. Feedback and adaptive behaviour in green buildings, Intelligent Buildings International, 1(4): 296-315.

CBRE. 2011. Retrofitting Existing Buildings: The low cost, high volume solution to climate change, Journal of Sustainability Asia Pacific. 4.

Chidiac, S.E., Catania, E.J.C., Morofsky, E., and Foo, S. 2011. Effectiveness of single and multiple energy retrofit measures on the energy consumption of office buildings, Energy, 36 (8) 5037-5052.

CIBSE. 2005. CIBSE AM10 - Natural ventilation in non-domestic buildings. The Chartered Institution of Building Services Engineers London.

Cohen S., Goldman C., Harris J. 1991. Energy savings and economics of retrofitting single-family buildings. Energy and Buildings 17, 297-311.

de Wilde, P. 2014. The gap between predicted and measured energy performance of buildings: A framework for investigation, Automation in Construction, 41 (0) 40-49.

de Meester, T., Marique, A.F., de Herde, A., and Reiter, S. 2013. Impacts of occupant behaviours on residential heating consumption for detached houses in a 
temperate climate in the northern part of Europe, Energy and Buildings, 57 (0) 313-323.

DesignBuilder. 2005. DesignBuilder website. Accessed August 282015. http://www.designbuilder.co.uk/.

DesignBuilder, Component block description, Accessed August 282015. http://www.designbuilder.co.uk/helpv3/Content/Component_Block.htm.

DOE. 2009. DOE to Fund up to $\$ 454$ Million for Retrofit Ramp-Ups in Energy Efficiency. Accessed August 28 2015. http://energy.gov/articles/doe-fund-454million-retrofit-ramp-ups-energy-efficiency.

DOE, EnergyPlus official webpage. Accessed August 28 2015. http://www.energy.gov/.

Fabi, V., Andersen, R.V., and Corgnati, S.P. 2013. Influence of occupant's heating setpoint preferences on indoor environmental quality and heating demand in residential buildings, HVAC\&R Research, 19 (5) 635-645.

Gill, Z.M., Tierney, M.J., Pegg, I.M., and Allan, N. 2010. Low-energy dwellings: the contribution of behaviours to actual performance, Building Research \& Information, 38 (5) 491-508.

GOV. 2015. Green Deal: energy saving for your home. Accessed August 282015. https://www.gov.uk/green-deal-energy-saving-measures/overview.

Gram-Hanssen, K. 2010. Residential heat comfort practices: understanding users, Building Research \& Information, 38 (2) 175-186.

Guerra Santin, O., Itard, L., and Visscher, H. 2009. The effect of occupancy and building characteristics on energy use for space and water heating in Dutch residential stock, Energy and Buildings, 41 (11) 1223-1232.

Guerra Santin, O. 2013. Occupant behaviour in energy efficient dwellings: evidence of a rebound effect, Journal of Housing and the Built Environment, 28 (2) 311-327. 
Haas, R., Auer, H., and Biermayr, P. 1998. The impact of consumer behavior on residential energy demand for space heating, Energy and Buildings, 27 (2) 195205.

Haldi, F. and Robinson, D. 2008. On the behaviour and adaptation of office occupants, Building and Environment, 43 (12) 2163-2177.

Huang, K., Feng, G., Li, H. and Yu, S. 2014. Opening window issue of residential buildings in winter in north China: A case study in Shenyang, Energy and Buildings, 84 (0) 567-574.

Lee, Y.S., and Malkawi, A.M. 2014.Simulating multiple occupant behaviors in buildings: An agent-based modeling approach, Energy and Buildings, 69 (0) 407-416.

Ma, Z., Cooper, P., Daly, D., and Ledo, L. 2012. Existing building retrofits: Methodology and state-of-the-art, Energy and Buildings, 55 (0) 889-902.

Mavrogianni, A., Davies, M., Taylor, J., Chalabi, Z., Biddulph, P., Oikonomou, E., Das, P., and Jones, B. 2014. The impact of occupancy patterns, occupant-controlled ventilation and shading on indoor overheating risk in domestic environments, Building and Environment, 78 (0) 183-198.

Mulville, M., Jones, K., and Huebner, G. 2013. The potential for energy reduction in UK commercial offices through effective management and behaviour change, Architectural Engineering and Design Management, 10 (1-2) 79-90.

Raja, I.A., Nicol, J.F., McCartney, K.J., and Humphreys, M.A. 2001. Thermal comfort: use of controls in naturally ventilated buildings, Energy and Buildings, 33 (3) 235-244.

Roetzel, A. 2014. Occupant behaviour simulation for cellular offices in early design stages-Architectural and modelling considerations, Build. Simul., 1-14. 
Santamouris, M., Pavlou, C., Doukas, P., Mihalakakou, G., Synnefa, A., Hatzibiros, A., and Patargias, P. 2007. Investigating and analysing the energy and environmental performance of an experimental green roof system installed in a nursery school building in Athens, Greece, Energy, 32 (9) 1781-1788.

Silva, A.S., and Ghisi, E. 2014. Uncertainty analysis of user behaviour and physical parameters in residential building performance simulation, Energy and Buildings, 76 (0) 381-391.

Steemers, K., and Yun, G.Y. 2009. Household energy consumption: a study of the role of occupants, Building Research \& Information, 37 (5-6) 625-637.

Spataru, C. and Gillott, M. 2011. The use of intelligent systems for monitoring energy use and occupancy in existing homes, Intelligent Buildings International 3(1): 24-31.

Wei, S., Buswell, R., and Loveday, D. 2013. Factors affecting ‘end-of-day’ window position in a non-air-conditioned office building, Energy and Buildings, 62 (0) 87-96.

Wei, S., Jones, R., and de Wilde, P. 2014. Using building performance simulation to save residential space heating energy: A pilot testing, in: Windsor Conference 2014, Cumberland Lodge, Windsor, UK.

Wei, S. 2014. Preference-based modelling and prediction of occupants' window behaviour in non-air-conditioned office buildings, $\mathrm{PhD}$ thesis, School of Civil and Building Engineering, Loughborough University.

Yang, R., Wang, W. 2013. Development of multi-agent system for building energy and comfort management based on occupant behaviors, Energy and Buildings, 56 (0) $1-7$. 
Yu, Z., Fung, B.C.M., Haghighat, F., Yoshino, H., and Morofsky, E. 2011. A systematic procedure to study the influence of occupant behavior on building energy consumption, Energy and Buildings, 43 (6) 1409-1417.

Yun, G.Y. and Steemers, K. 2010. Night-time naturally ventilated offices: Statistical simulations of window-use patterns from field monitoring, Solar Energy, 84 (7) 1216-1231.

Zhang, Y and Barrett, P. 2012. Factors influencing the occupants’ window opening behaviour in a naturally ventilated office building, Building and Environment, 50 (0) 125-134.

Zmeureanu, R. 1990. Assessment of the energy savings due to the building retrofit, Building and Environment, 25 (2) 95-103. 